OPEN ACCESS

Edited by:

Pierre-Etienne Vandamme, Université libre de Bruxelles, Belgium

Reviewed by: Herve Pourtois, Catholic University of Louvain, Belgium Dominique Leydet, Université du Québec à Montréal, Canada

*Correspondence: Laetitia Ramelet laetitia.ramelet@gmail.com

Specialty section: This article was submitted to Elections and Representation,

a section of the journal

Frontiers in Political Science

Received: 07 April 2020

Accepted: 04 August 2020

Published: 17 September 2020

Citation:

Ramelet L (2020) Why Voting Does Not Imply Consenting.

Front. Polit. Sci. 2:5.

doi: 10.3389/fpos.2020.00005

\section{Why Voting Does Not Imply Consenting}

\author{
Laetitia Ramelet* \\ Swiss Graduate School of Public Administration, University of Lausanne, Lausanne, Switzerland
}

One of the reasons that elections have come to be so widely valued across the globe lies in their perceived ability to increase citizens' consent to be governed by their representatives. Yet, inversely, one may ask what election results tell us about citizens' consent. For instance, to what extent can election winners be assumed to enjoy citizens' consent? Does voting automatically imply consent to the outcome of the election? What does abstention mean? This paper addresses the question of what election results reveal about citizens' consent, from an empirically informed normative perspective. The question is of political importance, because the connection between voting and consenting is often exploited for political gain, and because representative institutions are now being increasingly questioned by citizens themselves. I plead for caution in any endeavor to interpret election results in terms of consent, and I argue that it would be wrong to assume, by default, that voters intend their vote to express consent. Rather, voters' motives can only be ascertained by asking voters about them, and cannot be deduced from their sole act of voting. In addition, much variation is to be expected regarding what is being consented to, and to what degree.

Keywords: consent, elections, legitimacy, representation, authority, turnout, sortition

\section{INTRODUCTION}

Elections are currently the dominant practice to select the very few of us who make decisions binding for everyone. However, in accordance with the concerns of the present research topic, there is an inevitable gap between, on the one hand, the institutional need for a system with procedures to settle the question of who gets to rule, and on the other, the complexity of citizens' own perspectives and relations to politics. One of the reasons that elections have come to be so widely implemented and valued across the globe lies precisely at the crossroads of these two dimensions: in their perceived ability to secure citizens' consent to be governed by their representatives, at least better than other systems can (Luhmann, 1983; Hampton, 1993; Manin, 1997; Przeworski, 2018). Yet, inversely, one may ask what election results tell us about citizens' consent (by election results, I mean both winners' score and turnout). For instance, to what extent can election winners be assumed to enjoy citizens' consent? Does voting automatically imply consent to the outcome of the election? What does abstention mean?

These questions are not only important to understand the functioning of representation, but also because the connection between voting and consenting can be exploited for political gain. Not by chance do most authoritarian regimes prefer to rely on (the pretense of) electoral procedures to provide democratic support for their claims to power (Von Soest and Grauvogel, 2017). However, even in free democracies, election results are often instrumentalized by various political actors (and their adherents), typically to support one's claims to legitimacy or to discredit one's opponents. 
Thus, claims to have the backing of a "silent majority", or to represent "the people" better than others, are not rare. Furthermore, in the current context of increasing questioning of representative institutions (which lies at the core of this research topic), the problem is all the more worthy of attention that it seems to mirror many citizens' actual preoccupations. It may also be of interest for the lively debates around sortition (Landemore, 2013; Vandamme and Verret-Hamelin, 2017; Courant, 2019; Bedock and Pilet, 2020), either as a substitute for or as a complement to elections, to attain a clearer picture of the connection between consent and elections, notably to assess what may get lost, in terms of consent, if we dispense of elections.

This paper thus seeks to address the question of what election results tell us about citizens' consent, from an empirically informed normative perspective. Thereby, it pleads for caution and nuances in any endeavor to interpret election results in terms of consent. I argue that it would be a mistake to presume voters' consent simply on the basis of their votes and that much variation is to be expected regarding what may be consented to and with what intensity. As we will see, with the help of the empirical literature, there is evidence of a great diversity in the motives and assessments of voters. These can only be ascertained by asking voters about them, and cannot be deduced from their sole act of voting. The same goes for abstention. The analysis starts with a philosophical definition of political consent, followed by an exposition of the reasons that election results may reveal something about it. From this perspective, three possible objects of consent are considered: consent to elected representatives' rule, consent to elections as a procedure, and consent to membership in a democratic community. Last, it remains to examine what abstention can indicate about consent.

For these purposes, a dialogue between the theoretical and empirical literature proves to be particularly fruitful, in the spirit of the present research topic. While philosophical contributions allow us to grasp the contours and workings of political consent, studies on electoral behavior identify general patterns regarding the motives behind voters' choices. This empirical literature investigates the various recurring factors influencing vote choice ${ }^{1}$ and turnout ${ }^{2}$ and, as part of such vast enquiries, the more specifically political motives underlying both. Political motives include the meaning attributed by a voter to their vote (or their abstention), as well as their evaluation of the candidates, the election results, and, more generally, their attitudes toward representative institutions. It is on the latter type of findings that the present paper will focus, as these are the elements that bring us the closest to the potential connection between a

\footnotetext{
${ }^{1}$ Factors influencing voter choice notably include "cleavages" (Lipset and Rokkan, 1967) within society [e.g., traditionally, socioeconomic disparities or, more recently, a gap between the "winners" and "losers" of globalization (Kriesi et al., 2008; Hooghe and Marks, 2018)] as well as preferences regarding specific issues that are seen as particularly important at the time of an election (Enelow and Hinich, 1984; Bélanger and Meguid, 2008).

${ }^{2}$ Among the many determinants of turnout, studies report, for instance, individual characteristics (such as age, education, social networks, political interest, or a sense of civic duty), institutional variables (such as compulsory voting), as well as characteristics of the election (such as campaign expenditures and closeness of the election) (Brady et al., 1995; Blais, 2000; Franklin et al., 2004; Blais and Daoust, 2020; for an overview of the literature, see Stockemer, 2017).
}

citizen's vote and their consent. I will, of course, not be able to provide a comprehensive analysis of this abundant literature. More modestly, my objective will be to warn about the intricacies of the interpretation of consent from election results.

\section{CONSENT, ELECTIONS, AND LEGITIMACY}

To begin, a few words are necessary to clarify what is meant here by political consent, which I define as a citizen's mental acceptance of his or her political condition. The term "political condition" comprises the institutionalized political power relations to which a citizen is subject. In a representative democracy, this refers to two main dimensions: authorities' power on the one hand, and fellow citizens' power on the other. While authorities possess the power of making or enforcing decisions that affect the citizen, his or her fellow citizens have the power of selecting (some of the) rulers and participating in certain public decisions, which also affects him or her. Both dimensions converge in the state's commands, which at times can express the will of both authorities and the majority of participating citizens. By "mental acceptance," I mean that one consents when one agrees internally to being subjected to one's authorities and fellow citizens, or in other words, when one is favorably inclined toward their power over oneself. All citizens may be subject to the state's power. However, in the case of the consenting citizen, this is not rooted exclusively in the state's brute coercive means. Rather, it also appears to the citizen to be morally appropriate and to constitute a reasonable source of constraints upon him or her.

A few remarks are in order to situate this definition within the literature on consent theory. The ambition to place consent at the center of political life derives from the rich tradition of early modern consent and contract theories (most emblematically, Grotius's, Hobbes's, Pufendorf's, Locke's or Rousseau's) and has a long legacy. In particular, my definition owes much to Horton (2012) and Greene's (2016) recent contributions, which view political consent as an internal, psychological phenomenon, although they do not mention the element of acceptance described above. Thus, according to Horton, political consent is rooted in citizens' "beliefs and attitudes" toward their institutions and rulers: "it is about the acknowledgment of [the] state as having authority-recognizing the right of the state to exercise state power by making laws, pursuing policies and enforcing

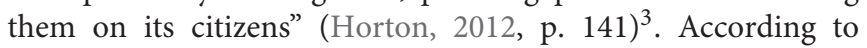
Greene, political consent stems from an individual's "positive governance assessment" on the performance of their rulers

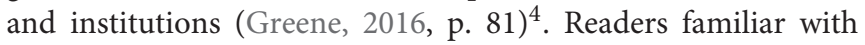
contemporary consent theories will also notice that this definition of consent as acceptance is distinct from the conception of consent employed in philosophical debates on political obligations. There, political consent is envisaged as a citizen's voluntary commitment to obeying a state's laws and authorities

\footnotetext{
${ }^{3}$ See also p. 142: "Thus, I consent to, or more properly recognize or acknowledge, the state as legitimate."

${ }^{4}$ See also: "a regime is legitimate insofar as it achieves actual quality consent to rule based on positive governance assessments" (p. 81).
} 
(see e.g., Pateman, 1979; Simmons, 1979; Klosko, 2005, 2018). However, most philosophers agree that such commitments are rarely made in practice (or at least not in meaningful circumstances), making consent of limited use when accounting for citizens' obligations and authorities' legitimacy ${ }^{5}$. I address some elements of these discussions below because certain philosophers have considered whether the act of voting counts as an act of consent in this obligating sense (Steinberg, 1978, p. 113131; Simmons, 1979, p. 91-93; Singer, 1994, p. 49, 50; Klosko, 2018, p. 352; Abizadeh, 2020, p. 4). However, my concern here is with consent as acceptance, which proves to be a more suitable candidate when accounting for legitimacy.

This brings us to the normative value of political consent. In keeping with the rich tradition of consent theory, if consent is required for a state's legitimacy, this is because the state embodies authorities' and fellow citizens' power over an individual citizen (in a democracy). This vast power can restrict individuals' freedom of action and can collide with the fact that all people are moral equals-unless they consent to these hindrances. Thereby, I concur with Horton and Greene again in the claim that political consent constitutes the source of the state's moral legitimacy. In Horton's words, legitimacy here means a state's "right" and "authority to govern" its subjects (Horton, 2012, p. 130). In Greene's, it refers to a regime's "appropriate standing to exercise power over its subjects” (Greene, 2016, p. 77). On her account, legitimacy results from the sum of "a high proportion" of individuals' actual consent: the more people consent, the more legitimate is a state (Greene, 2016, p. 87). Conversely, the less consent, the less legitimacy. This, of course, is not to say that such legitimacy provides complete justification for a state's powera point worth mentioning here, as the present paper focuses on the availability of consent. For this, certain conditions of justice also apply regardless of citizens' consent (including respect for human rights and the fair treatment of the state's citizens and residents at least; Horton, 2012, p. 135-137, Greene, 2016, p. 85) ${ }^{6}$. There is also the question of how informed such consent should be to be considered valid, which is a matter of debate. In any case, rulers should not manipulate consent via indoctrination and misinformation (Beetham, 1991, p. 8-11).

Given this general picture of consent and legitimacy, consent appears essential to the justification of political power, but it is also particularly tricky to identify, as a psychological phenomenon not openly accessible to others. This raises the question of what constitutes a potential sign of consent. In this paper, I approach this issue from the perspective of what election results reveal about citizens' consent. I do not suggest that election results are the only-or even the best-source of

\footnotetext{
${ }^{5}$ As Simmons puts it (Simmons, 1979, p. 100): "The challenge, then, seems to remain open to the modern-day consent theorist to show us how government by consent can be made a reality. In any event, however, the more plausible alternative is to turn our attention from consent to other possible grounds of political obligation."

${ }^{6}$ This distinction between legitimacy and justice is summarized as follows by Douglass (2020, p. 52), for whom, on the one hand, legitimacy refers to "the grounds for some person or body having the authority to rule," and, on the other, "questions of justice" relate to "how that authority should be exercised" (in reference to Kukathas).
}

such information. Rather, I aim to examine which relevant clues they can provide about consent, particularly in the light of the questions raised the introduction: to what can extent election winners be assumed to enjoy citizens' consent, and does voting imply consent to the election's outcome?

\section{ELECTIONS AND CONSENT}

Why consider election results (winners' score and turnout) as a potential source of information on such consent at all? I believe that an important reason to begin with lies in the institutional functions of elections as a designation mode for rulers. Historically, as Manin has shown (Manin, 1997, p. 83-90), it is largely due to their ability to embody the ideal of the "consent of the governed" that elections were established across Europe (and notably, favored over sortition). No later than with Locke's Second Treatise of Government was the close connection between them emblematically posited ${ }^{7}$. There is, arguably, a strong case for the belief that citizens will be more contented with their political condition if they get to choose their rulers, sanction them and even "fire" them in case their governance is deemed unsatisfactory. Conversely, this mechanism provides a strong incentive for representatives to govern responsively to citizens' preferences and needs if they want to stay in office, which is supposed to increase consent $t^{8}$. Thus, if elections were introduced to favor consent, it is worth examining what their outcome can tell us about it. First, regarding vote choice, election results seem to provide some information regarding whom citizens wish to see in power. Winners have obtained many votes, as well as more votes compared to other candidates. As such, it is possible (albeit uncertain) that winners might enjoy many citizens' approval. When this is the case, these citizens might consent to these individuals' power. Second, regarding turnout, the act of voting itself may signal a positive perception of the procedure, regardless of who receives citizens' votes. Again, when this is the case, these voters might consent to the winners' rule.

What speaks in favor of the latter hypotheses is that we know, from the empirical literature, that certain citizens locate the very meaning of the act of voting in its expressive dimension: of one's preferences for certain candidates, and/or certain policies, or one's care for the community's political decisions and institutions,

\footnotetext{
${ }^{7}$ In Locke's view (Locke, 2013), the legislative power should be composed of elected representatives (except in a direct democracy) to ensure citizens' consent to their laws, which constitutes a necessary condition for these laws' binding force (Second Treatise, \$134). When the legislators, or the government subordinated to them, fail to rule up to the task entrusted to them by the people (i.e., their society's preservation and common good), the people is free and well-advised to appoint new ones, see $\$ 212-223$.

${ }^{8}$ As Hampton puts it, voting can be seen as a "controlled revolutionary activity": Protest and opposition can be expressed and thus contained within the system itself, instead of turning into resistance to it (Hampton, 1993 p. 390, 391). In a similar vein, Luhmann considers elections as a channel for the expression of dissatisfaction, and therefore a suitable mechanism for the "absorption of protest" (Luhmann, 1983, p. 171). See also Przeworski (2018, p. 16), "We consent to being coerced-we could not live together peacefully unless we are coerced-because we can decide who should exercise coercion and how. People are free because they can choose their rulers," and Achen and Bartels (2016, p. 1): "In the conventional view, [d]emocracy makes the people the rulers, and legitimacy derives from their consent."
} 
among many possible motivations (Winkler, 1993; Jones and Hudson, 2003; Rogers et al., 2013) ${ }^{9}$. Such cases of "expressive voting" are often considered to provide one explanation (if not the only one) for the fact that many people make the effort to vote in spite of the very low likelihood for one single vote to break a tie, in reference to the famous "paradox of voting," an offspring of rational choice theory (Dowding, 2005; Geys, 2006; Aytaç and Stokes, 2019) ${ }^{10}$. This confirms that there are indeed attitudes and intentions of interest for our question at stake. However, it should be specified from the outset that election results can only be considered as a valid source of information when competition is fair for all potential candidates, the procedure is clean, and public information on the results is accurate $^{11}$. Fraud and misinformation make election results inapt to reveal anything on consent from the outset, which points to an important qualification to any connection between consent and election results.

The following analysis begins with the dimension of consent to representatives' rule, as the people being in power, and then moves to consent to the validity of elections as a procedure, which also touches upon the question of consent to one's belonging to a political community. In practice, these three dimensions may be combined in a single citizen's view. This may hold particularly in a context where representatives and institutions enjoy a high, enduring rate of consent. Nevertheless, as we will see, they point to distinct objects of consent and aspects of political legitimacy that are not always simultaneously given. The three dimensions have close affinities with Easton's notion, familiar to political scientists, of support for one's incumbents, institutions and national community (Easton, 1965, 1975; Norris, 2011), that may be useful to describe the intensity of consent (see below).

\section{CONSENT TO REPRESENTATIVES' RULE}

Let us start with the question of whether voting for someone implies consenting to that person's rule.

At first sight, voting for a candidate or a party seems to be congruent with an adhesion to that candidate's or party's ideals and goals in general, and/or to more specific policy proposals on that campaign. The best scenario is that of a re-election

\footnotetext{
${ }^{9}$ Fieldhouse warns us that it proves difficult to measure the various motives separately underlying a vote (Fieldhouse, 2018, p. 3): "Whilst the theoretical basis for expressive voting is well established, demonstrating it empirically is more difficult. The crucial problem is differentiating expressive motives from instrumental motives when, more often than not, they coincide. For example, people who have a strong preference for a set of policies are also likely to identify with a party advocating those polices."

${ }^{10}$ As Rogers, Fox and Gerber put it (Rogers et al., 2013, p. 91): "In a typical state or national election, a person faces a higher probability of being struck by a car on the way to his or her polling location than of casting the deciding vote. Clearly, traditional models cannot fully explain why and under which conditions citizens tend to vote."

${ }^{11}$ See Przeworski (2018, p. 45): "the belief that elections express active consent of free individuals obviously depends on whether people have a real chance to choose governments, most importantly, whether they are able to remove the incumbent rulers by the act of voting." See also Dahl (1971, p. 3) on what constitutes fair elections.
}

with such a mindset, as the voter is in a good position to judge the previous performance of the candidate(s). Likewise, on the aggregate level, stability over time of the parties in power may suggest a certain satisfaction with the status quo, provided new parties or candidates really stand a chance of entering the game. In some of these cases, voting for someone may even have an expressive function. For instance, so Franklin et al. (2004, p. 42) and Guerrero (2010, p. 274), elections are not only about who wins, but also about the winners' score. Communicating this support may be sensible, considering that the more votes a candidate (or party) has received, the more credibility he (it) will obtain. According to Huddy et al. (2015, p. 3), voting may also mean affirming one's social identity, as well as one's "emotional attachment" to a party and the people it represents ${ }^{12}$. This may well go along with the wish to "protect and advance group status," by contributing to the group's electoral victory (id.). In such cases, it seems plausible to infer this person's consent to being represented by the candidate or party of her choice from her vote. However, importantly for our concern, by far not every vote for a certain candidate or party fits this "ideal" description. Let us consider a few tricky situations for consent's interpretation to see what this means.

There are, to begin, cases in which a citizen votes for a candidate or party that they do not see as the best overall option. At times, the chosen option remains one they adhere to, as in certain cases of "strategic voting": A voter does not vote for their favorite party (or candidate) because it is unlikely to win seats, but the voter opts instead for a larger party (or a more popular candidate) that they prefer among the perceived relevant options (Blais and Degan, 2019). Yet a more problematic case is that of the citizen who votes not so much for a candidate or party as against another candidate or party (Medeiros and Noël, 2014; Caruana et al., 2015). Thus, according to Caruana et al. (2015, p. 775), negative partisanship "may motivate individuals to engage in behaviors that disadvantage their disliked party, regardless of the benefits expected for a preferred party (if they have one)." As a recent example, in the election of the French president Emmanuel Macron in 2017, many French citizens claimed to have voted against his adversary Marine Le Pen (and her party the Front National) rather than for him (and his En Marche!), in spite of doubts, sometimes strong ones, as to his suitability for the office ${ }^{13}$. Clearly, picking the lesser evil is far from enthusiastic support.

In this vein, another interesting type of example is that of the "protest vote." As Alvarez et al. (2018) have shown, there are several different types of protest votes, but the general idea is that a voter may cast a protest vote for a controversial party (or

\footnotetext{
${ }^{12}$ See also Fieldhouse (2018) and Hamlin and Jennings (2019, pp. 337-339) on voting as the expression of identity.

${ }^{13}$ For testimonies, see in the media e.g., Annabel Benhaiem, "Ils veulent rappeler à Emmanuel Macron qu'ils ont voté contre Marine Le Pen et non pas pour lui," Huffpost, 08.05.2017 (retrieved December 18, 2018 https://www.huffingtonpost. $\mathrm{fr} / 2017 / 05 / 08 /$ ils-veulent-rappeler-a-emmanuel-macron-quils-ont-vote-contrema_a_22075163/) or Olivier Bénis, "Présidentielle: un vote contre (le FN) face à un vote contre (le système)," franceinter, 07.05.2018 (retrieved December 18, 2018, https://www.franceinter.fr/politicalitique/presidentielle- un-vote-contre-lefn-face-a-un-vote-contre-le-systeme).
} 
candidate) to signal their discontent with other, more established parties (or candidates) ${ }^{14}$. In certain cases, this motive converges with an adhesion to the chosen party's position on issues considered to be important by the voter (Passarelli and Tuorto, $2018)^{15}$. Yet, in other cases, quite interestingly for our concerns here, a protest vote stems from the wish to send "a targeted signal of disaffection to one's most-preferred political party" (Kselman and Niou, 2011, p. 396). This does not necessarily entail a genuine endorsement of the chosen party's position, but is, first and foremost, intended to incite one's usual party to revise their positions on certain issues. (There are also protest votes aiming to communicate a general dissatisfaction with the dynamics of the current electoral system. I will return to these cases below).

Next, another example questioning the equation of a vote for someone with consent to her being in office is what, exactly, it means to consent to this candidate's rule. Selecting a candidate (or party) does not mean approving of all of her previous actions, nor of all of her agenda and intentions for her future mandate. If small divergences are frequent, a more dramatic example illustrates this point even more effectively. Jair Bolsonaro's election to the Brazilian presidency in 2018 fueled much controversy due to numerous problematic statements on his part, such as homophobic insults and allusions to the appeal of brute violence. This fed a widespread worry that voting for him implied consciously endorsing grave disrespect for human rights. Yet many Brazilians claimed to have voted for him out of a hope for more safety for the country, and in spite of other of his positions that they in fact condemned (whether this is a normatively coherent stance is a distinct question $)^{16}$. Hence, supporting a candidate (party) need not entail adhesion to all the aspects of her (its) rule, and may come with quite diametric judgments on her quality. This again evokes various possible degrees of consent.

These examples raise the question of how much support is necessary to speak of consent at all. My answer is that this cannot be determined without consulting the voter on the meaning he attributes to his vote, and his expectations. Indeed, as argued above, what constitutes political consent is determined by the individual's own perspective. Setting an independent threshold for what counts as consent or not only drives us away from it. What these scenarios suggest, however, is that political consent may come with various degrees of support, ranging from resignation to adhesion.

\footnotetext{
${ }^{14}$ See Kselman and Niou (2011, p. 414) for a noteworthy similarity between strategic voting and protest voting: "While strategic voters abandon their mostpreferred party in order to affect the current election's outcome, protest voters do so for the sake of downstream quality improvements."

15 "Political protest matters in voting behavior, but the groundbreaking result in the case of the M5S (the Five Star Movement in Italy) is that dissatisfaction with the system and/or elite performance has a stronger effect when coupled with ideological or issue preferences" (Passarelli and Tuorto, 2018, p. 10).

${ }^{16}$ In the media, see e.g., Diogo Rodriguez, "Why people vote for Jair Bolsonaro," Brazilian Report, 28.08.2018 (retrieved December 12, 2018, https://brazilian. report/power/2018/08/28/esther-solano-jair-bolsonaro/) or Chantal Rayes, "La peur et la corruption, piliers du succès de Bolsonaro," Le Temps, 26.10.2018 (retrieved December 12, 2018, https://www.letemps.ch/monde/peur-corruptionpiliers-succes-bolsonaro).
}

The possibility of accepting rulers one does not like is part of the very basic features of representative institutions, insofar as such actions flow from a more encompassing consent to the procedure of elections. If available, consent to the procedure can facilitate overall consent, even for citizens who voted for a candidate or party that did not win the election. In a proportional mechanism, this can also account for overall consent, in spite of the fact that many representatives were elected by other citizens than one's self ${ }^{17}$. This brings us to the question of whether casting a vote may be a potential sign of consent to elections as a collective decision-making mode qualified to confer legitimacy. What does an individual's participation, and on the aggregate level, turnout, reveal about consent?

\section{CONSENT TO ELECTIONS AS A PROCEDURE}

In what follows, I aim to show why, even if there may be good reasons in the abstract to consent to the outcome of an election one has participated in, this nonetheless depends again on the citizens' own perception of it, and on the context of the election. It seems quite intuitive that one's participation may proceed from one's faith in the legitimating function of the procedure, and go hand-in-hand with an inclination to accept the elected candidates' rule ${ }^{18}$. This raises the question of whether citizens "show consent by voting" (Brennan, in Brennan and Hill, 2014, p. 26). For instance, according to Miles (2015, p. 366), voting may provide a "means for the public to express their consent to be governed", as a positive assessment of a general "procedural fairness" characterizing authorities' governance ${ }^{19}$.

To begin, a good case in point is the citizen who votes out of civic duty-for instance, out of the conviction that one must do one's share in the collective decision-making efforts, or that one's right to vote is to be cherished, or that democratic institutions require high rates of participation to have their valuable effects, or even to subsist (Jones and Hudson, 2003; Blais and Galais, $2016)^{20}$. It seems likely that those who see moral worth in the procedure are, in principle, willing to accept its outcome for this very reason.

Moral motives aside, is there a more general "conceptual connection between voting and consenting," as Singer would have it (Singer, 1994, p. 50)? According to this argument, voting means accepting the results even if one did not vote for the winners: either because one acknowledges the legitimacy of the

\footnotetext{
${ }^{17}$ In fact, both Anderson et al. (2005, p. 139, 140) and Martini and Quaranta (2019, p. 357) find "losers" to be more satisfied with the rules of the game in proportional systems than in majoritarian ones. More on "loser's consent" below.

${ }^{18}$ For a theory of procedures as a decisive source of legitimacy, see Luhmann (1983).

${ }^{19}$ See also p. 373: "For some, voting is tacit political system endorsement-an act which signifies consent to be governed. When these people feel valued by their system of government, they are more likely to vote. For these individuals, voting is not motivated by a desire to influence the outcomes of elections, nor by a sense of civic duty; rather, voting expresses validation of the system."

${ }^{20}$ Note that asking a citizen whether she considers voting to be a civic duty may induce a social desirability bias toward a positive answer, which makes it more complex to track her actual motives (Fieldhouse, 2018, p. 5).
} 
procedure, or out of respect for the other citizens' judgments and preferences.

What first speaks in favor of the argument is that it is, indeed, one of the characteristics of consent to be compatible with very diverse feelings. One may agree to something without enthusiasm, without liking the consented option, or without holding it for the best on $\mathrm{e}^{21}$. Thus, if one values one's institutions and/or one's fellow citizens' choice, one may accept the results as legitimate even if one finds them disappointing, or even infuriating. This possibility is confirmed by the literature on "losers' consent," i.e., those whose favorite candidates do not make it to the seat of power, or at least not to a dominant position. In their cross-national study, Anderson et al. (2005) find that losers tend to be less supportive of their authorities than winners, yet not up to the point of losing faith in the system. At least, this seems to hold as long as they believe they have a chance of winning next time ${ }^{22}$. To further highlight the compatibility of consent to procedure and low satisfaction with its results, let us mention Dompnier and Berton's observation that opponents of the French prime minister's party tend to be "more critical of the democratic rules, but only when applied to the French case and without rejecting them" (Dompnier and Berton, 2012, p. 341). This evidences that attitudes toward a system's core values and principles must be distinguished from attitudes toward their implementation in a specific context, which points to further subtleties regarding consent's object. In a similar vein, one may be discontented with the options available in one particular election without questioning the legitimacy of the procedure overall. Thus, Balme et al. speak of a widespread paradox "opposing the sacralisation of elections with a criticism of elected representatives" (my translation, Balme et al., 2003, p. 447).” This occurs when one values the opportunity to vote as a civic right in the abstract but is dissatisfied with the "constrained" options available in a particular election ${ }^{23}$. In sum, all of this pleads for

\footnotetext{
$\overline{{ }^{21} \text { On this point, see Wertheimer }}$ (2000, p. 569), Owens (2011, p. 412, 413) and Schnüringer (2018, p. 22) on consent in interpersonal ethics.

${ }^{22}$ One of the study's overall conclusions is that losers are "almost uniformly less positive in their evaluations than winners," but nonetheless, that "more losers are satisfied with the functioning of democracy than dissatisfied" (Anderson et al., 2005, p. 159). Their indicators are the following: respondents' overall satisfaction with democracy, belief in the fairness of the last elections, and assessment of the responsiveness of parties to the population's concerns. For the similar conclusion that losing entails lower support for the system, see also Rich and Treece (2018) on Germany, but for more positive results on losers' support of democracy, see Esaiasson (2011), according to whom it is more accurate to conclude that winners usually "become more supportive," while losers "retain their level of support from before the election" (p. 103). We also know from this literature that how deeply losing affects one's attitudes toward the system is influenced by various contextual factors. For instance, still according to Anderson et al. (2005, p. 108, 109), losing is more tolerated in established democracies than in more recent ones (in their study, former communist countries in Europe). Martini and Quaranta also observe that incumbents' positive performance also impacts positively upon positive losers' attitudes (Martini and Quaranta, 2019). As another factor, both Anderson et al. (2005, p. 139, 140) and Martini and Quaranta (2019, p. 357) find losers to be more satisfied with the rules of the game in proportional systems than in majoritarian ones.

23 "L'adhésion au vote s'accompagne d'une insatisfaction profonde et largement partagée quant à son exercice pratique. Le choix électoral est jugé ardu et l'information défaillante, car il est difficile de connaître l'ensemble de l'offre électorale. Au-delà de la difficulté technique et politique à s'orienter parmi les
}

a distinction between consent and approval (or support): While approval of the incumbents seems likely to produce consent to their power, it is no necessary condition for it. Hence, consent to the procedure can be available in spite of low support for the elected candidates.

A second way to make the case for an inference from citizens' electoral participation to their consent to the procedure is to appeal to the point of an act of vote. According to Singer (1994, p. 50), it is "reasonable to assume" that voters consent to the procedure (at least in general), because otherwise it would be pointless to vote: "What would be the sense of having a vote if no one ever accepted the result of the vote?" To my mind, the first problem with this argument is its reliance on a presumption of the voter's coherence, in addition to a statement on what coherence entails (such as "voting is only intelligible if one is ready to accept the results"). As argued above, this position tends to set aside citizens' actual attitudes, while it is precisely their own perspective that matters to consent. As a second objection, the argument loses of its appeal in conflictual contexts (even in a fair election without fraud). This can happen when the election exacerbates important divisions within the political community, or if the winners are deemed profoundly dangerous by some of the voters. If one considers their rule to be very detrimental to the common good, one may cast doubt on the value of elections at all, which erodes consent to the procedure. One may come to question the very principle of elections, or alternately, a more specific aspect of one particular system. As to the latter, one example consists of rejections of the American electoral college system, after an elected president wins, thanks to the majority of state electors, in spite of having obtained fewer individual votes than his rival ${ }^{24}$.

These scenarios raise the question of whether it is possible to vote without even considering the procedure as legitimate from the outset. I believe this can be the case when one sees that particular election as illegitimate (while recognizing the value of elections in principle), due to the presence of a contestant that should not even be considered as a potential ruler, in one's view. This typically applies to individuals who hold that a legitimate ruler must fulfill some substantive conditions, in addition to procedural ones, such as a genuine commitment to the respect of human rights or a lack of corruption. For them, it may be sensible to cast a vote in spite of their potential dissent, merely in the hope of some causal influence, at least in the expressive function of the vote. We may also invoke Aytaç's and Stokes's "theory of costly abstention" (Aytaç and Stokes, 2019, p. 28): When a person really cares about the outcome of an election, the idea of abstaining can make her feel internal "dissonance" and "disutility" for not

programmes, le personnel politique est tenu en suspicion: 'On vote pour quelqu'un mais on sait pas ce qu'il y a derrière'. Les groupes expriment également un hiatus entre l'offre électorale et leurs attentes, ils ont le sentiment de faire des choix contraints: 'Si je trouve par exemple que toutes les têtes de liste proposées ne sont pas en adéquation avec ce que moi je voudrais, je peux pas voter non plus pour mon voisin. [... ] J'ai pas le choix, c'est ces gens-lä' (Balme et al., 2003, p. 445).”

${ }^{24}$ See e.g., Andrew Prokop, "Why the Electoral College is the absolute worst, explained," in Vox, 19.12.2016 (October 25, 2019), https://www.vox.com/policyand-politics/2016/11/7/12315574/electoral-college-explained-presidentialelections-2016. 
participating, in spite of her awareness of the little impact of her vote (Aytaç and Stokes, 2019, p. 56). Yet in any case, the answer to this question can only be given by the voter himself, for the same reason as above: it is the citizen's own vision that counts for consent, which cannot be replaced by speculation on the sensibleness of his motives. What these cases reveal, however, is that consent cannot simply be inferred from participation.

\section{CONSENT TO MEMBERSHIP IN A COMMUNITY}

It emerges from these examples that another object of consent must be examined, namely one's relationship to one's fellow citizens. To what extent does the act of voting manifest consent to membership in one's political community?

Let us start with cases supporting such a hypothesis. According to Winkler (1993, p. 331), voting is sometimes understood as "a meaningful participatory act through which individuals create and affirm their membership in the community" and their "sense of attachment" to it. Thus, voting may be an occasion to concretize one's feeling of belonging to one's political community. Identification with one's community may also be correlated with the view that voting constitutes a civic duty (Blais and Galais, 2016, p. 61). As we have seen above, this sense of duty can be positively linked to one's acceptance of the results. Indeed, when the communitarian incentive to vote favors an inclination to accept elections results (if not approve of them), this brings us back to consent to elections as a valid procedure, but seen from a different angle. This time, valuing the procedure may be due to a certain deference for one's fellow citizens' voices, and a willingness to let the majority's preferences and decisions win.

These cases confirm that a sense of citizenship may provide an incentive to vote, but do not suffice to establish a causal connection between consent to membership in one's community and voting. However, what they illustrate is how the three main dimensions of consent (to rulers, procedure, community) can be closely interrelated. One's feeling of belonging to a community may be a source of consent to elections as a relevant decisionmaking procedure, and hence to the winners' rule. Note that this does not mean that consent to membership in the community is a necessary condition for consent to procedure. Less engaged citizens may consent to the procedure for practical benefits of coordination, among an aggregate of individuals that they feel no particular moral or affective ties with, while accepting their share of influence.

However, other cases exemplify how these three objects of consent (to rulers, procedure, community) can also come apart. Some protest votes are not only addressed as a warning to a certain party, but more broadly as an "expression of dissatisfaction with mainstream parties and/or mainstream politicians," and "with politicians as a class and political institutions more generally" (Birch and Dennison, 2019, p. $111,112)$, or in other words, with a perceived political “establishment" (Gabriel, 2017, p. 288) ${ }^{25}$. This may go hand in

\footnotetext{
25 "Für viele Wähler scheint das Votum für eine Protestpartei Ausdruck einer diffusen Mischung aus Zukunftsangst, Unzufriedenheit mit der politischen
}

hand with an identification with "the people" on the other, who would be poorly represented by a "corrupt elite" comprising representatives, but also more generally the powerful (Mudde, 2007, p. 23, 65, 66; Gabriel, 2017, p. 294). In such cases, consent to membership in the community seems to be available without consent to its current authorities, a tension that finds its expression in the protest vote. This may still be compatible with consent to elections as a procedure, unless this situation is attributed to representative institutions themselves, which points to another gray area. Overall, what we can conclude is that consent to membership in the community can be available both with or without consent to elected candidates' rule. Hence, it does not qualify as an obvious source of consent to representatives' power.

\section{ABSTENTION, CONSENT, AND LACK OF CONSENT}

Now that we have seen a variety of nuances related to the relationships between voting and consenting, it remains to address those that exist between abstention and consent. Abstention is, in fact, quite paradigmatic of the problems pertaining to the interpretation of consent. It proceeds from very diverse motives that may just as well point to consent or a lack of it, as well as various shades in between. Like participation, abstention is influenced by various individual factors (such as age or level of education, for instance), but also, and more interestingly for our concern, by political ones (Braconnier and Dormagen, 2007; Dris-Ait Hamadouche, 2009; Dupuis-Déri, 2020, p. 109-112). As Hill observes (Hill, 2002, p. 85, 86), even though abstention is sometimes interpreted as some form of "tacit consent," 26 the plurality of factors conditioning abstention makes it difficult to deduce anything from it at first sight:

Silence is at best ambiguous. It can mean many things. It may mean: I'm homeless and find it difficult to register'; I'm experiencing an economic crisis and am too demoralized to vote'; I'm ill'; I'm isolated'; I'm a new migrant'; "I have literacy and numeracy problems"; I'm immobile'; I'm a young voter alienated from the political system'; "I have low feelings of either internal or external political efficacy (or both)" or even I'm perfectly satisfied with things as they are'. But it is difficult, if not impossible, to

Entwicklung und Misstrauen gegen die gesellschaftlichen und politischen Führungsgruppen zu sein. Wie Oskar Niedermayer in einer kürzlich gemeinsam mit Jürgen Hofrichter publizierten Analyse der Wahlerfolge der AfD aufzeigte, entscheidet sich mancher deutsche Wähler weniger auf Grund seiner Zustimmung zu den inhaltlichen Angebote für diese Partei, sondern weil er 'von anderen Parteien enttäuscht ist und Ihnen einen Denkzettel verpassen will' (Niedermayer und Richter, 2016, S. 283;" Gabriel, 2017, p. 288).

26 "It is often suggested that abstention is tolerable (even desirable) because it is really a form of political expression connoting tacit consent to the regime. Those who conceive voting purely as a mechanism for registering dissatisfaction, regard the silence of the abstainer as an eloquent expression of contentment with the political system. Such claims are problematic because largely speculative and in some cases, counter-factual: in the USA, for example, the 1996 National Election Study found that non-voters tended to be twice as dissatisfied as voters about the state of democracy in America (Wattenberg, 1998, p. 3). We also know that abstainers tend to perceive government as unresponsive and that their vote will be ignored; accordingly, they abstain" (Hill, 2002, p. 85). See also Ragsdale (2017) on American nonvoters. 
perceive which of these categories is explaining the abstention of any particular person.

Regarding the connection between abstention and satisfaction, Bühlmann et al. (Bühlmann et al., 2003, in a study of Swiss elections to the National Council in 1999) observe it to hold for nonvoters with high rates of trust in rulers and institutions (approx. 10\% of non-voters), as well as for non-voters who consider themselves "incompetent" on political matters but are confident in others' judgments (4\%). This tendency thus makes it very easy to instrumentalize abstention in favor of the status quo. Yet abstention can just as well result from dissatisfaction, with various aspects at that. Thus, still in Bühlmann et al.'s study, non-voters uninterested in politics tend to be distrustful of current rulers, but generally satisfied with democracy (33\%). This sounds compatible with consent as the acceptance of one's political condition overall. However, a more problematic type of non-voter is not only suspicious of rulers' competence and good intentions, but also dissatisfied with democracy in general (7\%). As Kemmers observes (Kemmers, 2017, in a study on the Dutch 2012 parliamentary elections and "populism"), such distance from the system can take the specific form of a rejection of political parties and the way political power is organized around them. This provides a good ground for abstention: "it is not at all self-evident that an ideal-typical populist citizen could be persuaded to vote for any party, even one that claims to challenge the establishment," because even the latter would remain bound by "the rules of the game" (Kemmers, 2017, p. 383) ${ }^{27}$. Ryabchuk (2016, examining South African national elections in 2014), and Schultheis (2017, interviewing German long-term unemployed non-voters) also refer to feelings of low political efficacy that reveal a very negative perception of the ability of rulers and procedure to change anything, no matter whom one votes for. This invokes again the distinction between the available offer in a specific campaign and the general principles of elections. It is nonetheless difficult to determine without asking each of these persons whether they no longer consent at all to their political condition, or whether they still consent, albeit to a very low degree. Yet all these cases plainly illustrate that abstention can be explained by motives and attitudes that do not bode well for consent. Interestingly, abstention can sometimes even be intended as a "message to the world of politics" (Kemmers, 2017, p. 385) or as a "demonstrative political statement" (Schultheis, 2017 , p. 19, my translation). See this extract from one of Kemmers's interviews (Kemmers, 2017, p. 385):

\footnotetext{
${ }^{27}$ See also Hooghe et al. (2013, p. 249,250$)$ for a similar thesis, related to citizens' distrust in both officeholders and institutions: "First, a lack of political trust can lead to a decline in voter turnout. If the distrust remains limited to current office holders, this might serve as an incentive to vote as citizens will be motivated to replace current politicians with their challengers. In this way, voting opposition parties into power might in the long run lead to a renewal of trust in the political system among the population. However, if distrust extends to the basic rules of democracy itself, there is less reason to vote since citizens no longer assume that their vote will make a difference. Especially with regard to the electoral process itself, Alvarez et al. (2018) have demonstrated that citizens are less motivated to vote if they do not believe the electoral procedure will be administered in a fair manner. While it might be true that political distrust will be associated with various non-institutionalized forms of political participation, it is most likely to deter electoral participation.”
}

It's just not true that you're not taking your civic responsibility if you don't vote. Not voting is also an expression of I'm through with it, I don't want this any more.' This is not my government, not my representation. And that's also an expression, that's also a form of voting ${ }^{28}$.

When voting is compulsory, a similar option is the use of blank or (intentionally) null ballots: these have been reported to express discontent with the available options, and "the political status quo-although not with democracy” (Cohen, 2018, p. 412, in 14 Latin American countries; Katz and Levin, 2016, in Brazil).

Some of these examples suggest that one may refuse to vote precisely because one does not wish one's vote to be taken as consent (see also Miles, 2015, p. 363). This reveals a perceived connection between voting and consenting, as well as of its potential for manipulation, or at least misperception. Thus, with a view to the legitimating appearance of a vote, Hanna (2009) makes the case for a moral obligation not to vote under certain circumstances, and Dupuis-Déri (2020) for a systematic abstention. Yet, as Hanna (2009, p. 283) and Ryabchuk (2016, p. 46) note, along with Kemmers's interviewee above, some actors may consider it strategic to discredit non-voters' silence as an irresponsible neglect of one's civic duty (to vote). This again attests that abstention can not only mean, but also be said to mean, pretty much everything and its contrary.

\section{CONCLUSION}

Overall, the general conclusion on the relationship between consent and election participation and results is that interpreting their results (winners' score, turnout) in terms of consent requires much circumspection, in spite of their apparent connection, and even when procedures are strictly respected. The combination of theoretical perspectives on consent and empirical findings on electoral behavior has shown why inferring consent simply from citizens' votes is not warranted. It is also wrong to assume, by default, that voters intend their vote to express consent, even though this can sometimes be the case. Rather, it is only by asking voters about the meaning of their votes that we can hope for certainty. This is all the more important, given that it is the citizens' own individual perspectives that count for consent and its legitimating effects. Therefore, it cannot be replaced by speculation on the sensibleness of their motives, or what they consider to be important.

In other words, little can be known about consent by simply looking at an election's results (winners, turnout). The vast amount of work required for a solid empirical case study on an election only confirms this (not to mention the fact that its findings are published quite a while after the election and are difficult to assess without the relevant research training). In a context of increasing citizen dissatisfaction with existing representative institutions, it seems timely to recall this uncertainty. The many examples discussed in the course of the analysis confirm that complex cases are not only interesting in theory, but also frequent in practice. Among the various

\footnotetext{
${ }^{28}$ Many more testimonies of abstention for political reasons can be found in Dupuis-Déri (2020).
} 
subtleties to take into account, I have highlighted the following. First, regarding the various objects of consent: Consent to elected representatives' rule (as these particular persons' rule), to elections as a procedure, and consent to membership in the community may be jointly available, but need not be. Second, political consent comes in degrees, ranging from resigned consent to convinced support, and including everything inbetween. Third, voting is compatible with a very low degree of consent, or even dissent. This is notably the case when a citizen is opposed to the available options, or with some of a chosen candidate's or party's positions, and sometimes also even to the procedure.

Before concluding with the meaning of these findings for relations between citizens and their representative institutions, allow me to point out possible implications for debates around the comeback of sortition as a designation mode for rulers (Landemore, 2013; Vandamme and Verret-Hamelin, 2017; Courant, 2019; Bedock and Pilet, 2020), although this is not the primary purpose of this paper. What emerges from this discussion is the potential to deactivate one objection against sortition: the objection that elections are necessary for legitimacy because they are the way citizens can express their consent to their rulers' power, and hence give them authority. We have seen that voting does not entail consent (nor does abstention), and is by far not unanimously considered to perform this function ${ }^{29}$. In addition, we have seen that consenting to an option does not mean regarding it as the best one, nor as the only one. This means that consent to elections as procedures does not, by itself, preclude potential consent to other procedures that may even be preferred, such as sortition. Nor is the conception of consent used in this paper incompatible with sortition. Arguably, if consenting means mentally accepting one's political condition (one's authorities and fellow citizens' power over oneself), there is no element here that rules out the replacement or combination of elections with sortition for such acceptance to be secured. These remain theoretical points at this stage, but they may be of some interest to continue the debate. This being said, I believe that a more decisive question to settle, if we acknowledge the importance of political consent for legitimacy, is an empirical one: namely, which of the two systems would obtain higher rates of consent. It remains, indeed, to address the classical assumption that being able to participate in the choosing of one's rulers, even to a limited extent, tends to increase consent to their power. There are, of course, other reasons, not directly related to consent, to ponder if we were to choose between elections and sortition, such as the ability of elections to give all citizens an equal share in the community's power (at least in terms of the possibility of controlling who should represent them), or the possibility for electoral competition to select rulers that had to acquire a significant knowledge of the political system and the issues to be addressed within it (in order to be elected). With these

\footnotetext{
${ }^{29}$ What is, however, well perceived is the potential for the instrumentalization of election results. One benefit of dispensing with elections may rest in shutting down this possibility, although this depends upon how severe the risk is estimated to be.
}

remarks, I am only considering the sort of arguments that may be advanced in reference to consent and the acceptance of the state's power.

To conclude, these final remarks are neither intended as a contestation of the legal weight of election results, nor of the authority of the winners to make decisions on behalf of the community. Nevertheless, as argued in the introduction, our need for legal procedures to designate rulers does not suffice to capture the many facets of citizens' experiences of and views on politics, as these follow their own logic. Due to this gap, representative institutions carry with them certain inherent risks of misinterpretation and opportunism: notably, including the risk of political actors availing themselves of the population's consent to their rule, as well as to some of their specific intentions and decisions; or the risk of conflating support, unenthusiastic consent, and the mere desire for some causal influence; or the risk of distorting some citizens' perspectives by selecting arbitrary criteria for the interpretation of election results. Hopefully, the present analysis provides reasons to avoid speaking in the name of citizens without properly consulting them, and keep in mind the distinctiveness of each citizen's point of view. In sum, we have more than enough reason to remain critical about what election results can tell us about citizens' consent.

\section{DATA AVAILABILITY STATEMENT}

The original contributions presented in the study are included in the article/supplementary material, further inquiries can be directed to the corresponding author/s.

\section{AUTHOR CONTRIBUTIONS}

The author confirms being the sole contributor of this work and has approved it for publication.

\section{FUNDING}

This article was written while I was working as a research and teaching assistant at the University of Lausanne, at the Faculty of Law, Criminal Justice and Public Administration.

\section{ACKNOWLEDGMENTS}

For insightful comments on earlier versions of this article and stimulating discussions about its topic, I would like to thank the three reviewers of this article, Pierre-Étienne Vandamme, Camille Bedock, Sandrine Baume, Clémence Demay, HenriPierre Mottironi, Simon Stückelberger, Hannah Werner, Ramon van der Does, as well as audiences in Bordeaux (2019), Lucerne (2019), and Geneva (2020). 


\section{REFERENCES}

Abizadeh, A. (2020). Representation, bicameralism, political equality, and sortition: reconstituting the second chamber as a randomly selected assembly. Perspect. Politics 1-16. doi: 10.1017/S1537592719004626 Available online at: https://www.cambridge.org/core/journals/perspectives-on-politics/ article/representation-bicameralism-political-equality-and-sortitionreconstituting-the-second-chamber-as-a-randomly-selected-assembly/ 4DC09D5CFA379C756E5F7E67C24A00B8

Achen, C., and Bartels, L. (2016). Democracy for Realists: Why Elections Do Not Produce Responsive Government. Princeton: Princeton University Press. doi: 10.1515/9781400882731

Alvarez, R. M., Kiewiet, D. R., and Núñez, L. (2018). A taxonomy of protest voting. Ann. Rev. Political Sci. 21, 135-154. doi: 10.1146/annurev-polisci-050517-120425

Anderson, C. J., Blais, A., Bowler, S., Donovan, T., and Listhaug, O. (2005). Losers' Consent: Elections and Democratic Legitimacy. Oxford: Oxford University Press. doi: 10.1093/0199276382.001.0001

Aytaç, S. E., and Stokes, S. C. (2019). Why Bother? Rethinking Participation in Elections and Protests. Cambridge, MA: Cambridge University Press. doi: $10.1017 / 9781108690416$

Balme, R., Marie, J.-L., and Rozenberg, O. (2003). Les motifs de la confiance (et de la défiance) politique: intérêt, connaissance et conviction dans les formes du raisonnement politique. Rev. Intern. Politique Comp. 10, 433-461. doi: $10.3917 /$ ripc. 103.0433

Bedock, C., and Pilet, J. (2020). Who supports citizens selected by lot to be the main policymakers? A study of french citizens. Govern. Oppos. 1-20. doi: 10.1017/gov.2020.1 Available online at: https://www.cambridge.org/ core/journals/government-and-opposition/article/who-supports-citizensselected-by-lot-to-be-the-main-policymakers-a-study-of-french-citizens/ 4F2BAF2C2371977E6CCC2F6689AC2B1F

Beetham, D. (1991). The Legitimation of Power. London: Macmillan. doi: 10.1007/978-1-349-21599-7

Bélanger, R., and Meguid, B. (2008). Issue salience, issue ownership, and issuebased vote choice. Elect. Stud. 27, 477-491. doi: 10.1016/j.electstud.2008.01.001

Birch, S., and Dennison, J. (2019). How protest voters choose. Party Politics 25, 110-125. doi: 10.1177/1354068817698857

Blais, A. (2000). To Vote or Not to Vote. The Merits and Limits of Rational Choice Theory. Pittsburgh: University of Pittsburgh Press. doi: 10.2307/j.ctt5hjrrf

Blais, A., and Daoust, J.-F. (2020). The Motivation to Vote. Explaining Electoral Participation. Vancouver: University of British Columbia Press.

Blais, A., and Degan, A. (2019). "The study of strategic voting," in The Oxford Handbook of Public Choice, Vol. 1, eds R. D. Congleton, B. Grofman, and S. Voigt (Oxford: Oxford University Press), 292-309. doi: 10.1093/oxfordhb/9780190469733.013.14

Blais, A., and Galais, C. (2016). Measuring the civic duty to vote: a proposal. Elect. Stud. 41, 60-69. doi: 10.1016/j.electstud.2015.11.003

Braconnier, C., and Dormagen, J.-Y. (2007). La Démocratie de l'Abstention: aux Origines de la Démobilisation Électorale en Milieu Populaire. Paris: Gallimard.

Brady, H., Verba, S., and Schlozman, K. (1995). Beyond SES: A resource model of political participation. Am. Political Sci. Rev. 89, 271-294. doi: 10.2307/2082425

Brennan, J., and Hill, L. (2014). Compulsory Voting: For and Against. Cambridge: Cambridge University Press. doi: 10.1017/СBO9781139649742

Bühlmann, M., Freitag, M., and Vatter, A. (2003). "Die Schweigende Mehrheit: Eine Typologie Der Schweizer Nichtwählerschaft," in Schweizer Wahlen 1999. Elections fédérales 1999, eds P. Sciarini, S. Hardmeier, and A. Vatter (Bern: Paul Haupt), 27-58.

Caruana, N., McGregor, R., and Stephenson, L. (2015). The power of the dark side: negative partisanship and political behaviour in Canada. Canad. J. Political Sci. 48, 771-789. doi: 10.1017/S0008423914000882

Cohen, M. J. (2018). Protesting via the null ballot: an assessment of the decision to cast an invalid vote in latin America. Polit. Behav. 40, 395-414. doi: 10.1007/s11109-017-9405-9

Courant, D. (2019). "Sortition and democratic principles. a comparative analysis," in Legislature by Lot, Transformative Designs for Deliberative Governance, eds J. Gastil and E. Olin Wright. (London: Verso), 229-248.

Dahl, R. (1971). Polyarchy. Participation and Opposition. New Haven, London: Yale University Press.
Dompnier, N., and Berton, R. M. (2012). How durably do people accept democracy? Politicization, political attitudes and losers' consent in France. French Politics 10, 323-344. doi: 10.1057/fp.2012.20

Douglass, R. (2020). Hobbes and political realism. Eur. J. Political Theory 19, 250-269. doi: 10.1177/1474885116677481

Dowding, K. (2005). Is it rational to vote? Five types of answer and a suggestion. $\mathrm{Br}$. J. Politics Intern. Relations 7, 442-459. doi: 10.1111/j.1467-856X.2005.00188.x

Dris-Ait Hamadouche, L. (2009). L'abstention en Algérie: un autre mode de contestation politique. L'Année du Maghreb 263-273. doi: 10.4000/anneemaghreb.588

Dupuis-Déri, F. (2020). Nous Nirons Plus aux Urnes. Plaidoyer pour L'abstention. Montréal: Lux.

Easton, D. (1965). A Framework for Political Analysis. Englewood Cliffs: PrenticeHall.

Easton, D. (1975). A re-assessment of the concept of political support. Br. J. Polit. Sci 5, 435-457. doi: 10.1017/S0007123400008309

Enelow, J. M., and Hinich, M. J. (1984). The Spatial Theory of Voting: An Introduction. Cambridge: Cambridge University Press.

Esaiasson, P. (2011). Electoral losers revisited - How citizens react to defeat at the ballot box. Elect. Stud. 30, 102-113. doi: 10.1016/j.electstud.2010.09.009

Fieldhouse, E. (2018). Being a voter: developing a survey instrument for expressive voting. J. Elections Public Opin. Parties 29, 1-23. doi: 10.1080/17457289.2018.1530679

Franklin, M., Eijk, C., Evans, D., Fotos, M., Hirczy de Mino, W., Marsh, M., et al. (2004). Voter Turnout and the Dynamics of Electoral Competition in Established Democracies since 1945. Cambridge: Cambridge University Press. doi: $10.1017 /$ СBO9780511616884

Gabriel, O. W. (2017). "Misstrauen und Protestwahl in europäischen Demokratien," in Parteien, Parteiensysteme und politische Orientierungen: Aktuelle Beiträge der Parteienforschung, ed C. Koschmieder (Wiesbaden: Springer), 287-306. doi: 10.1007/978-3-658-17922-9_14

Geys, B. (2006). 'Rational' theories of voter turnout: a review. Polit. Studies Rev. 4, 16-35. doi: 10.1111/j.1478-9299.2006.00034.x

Greene, A. (2016). "Consent and political legitimacy," in Oxford Studies in Political Philosophy, Vol. 2, eds D. Sobel, P. Vallentyne, and S. Wall (Oxford: Oxford University Press), 71-97. doi: 10.1093/acprof:oso/9780198759621.003.0004

Guerrero, A. (2010). The paradox of voting and the ethics of political representation. Philos. Public Affairs 38, 272-306. doi: $10.1111 / j .1088-4963.2010 .01188 . x$

Hamlin, A., and Jennings, C. (2019). "Expressive voting," in The Oxford Handbook of Public Choice, Vol. 1, eds B. G. Roger, D. Congleton, and S. Voigt (Oxford: Oxford University Press), 333-350. doi: 10.1093/oxfordhb/9780190469733.013.16

Hampton, J. (1993). "Contract and consent," in A Companion to Contemporary Political Philosophy, eds R. E. Goodin and P. Pettit (Cambridge, MA: Blackwell), 379-393.

Hanna, N. (2009). An Argument for Voting Abstention. Public Aff. Q 23, 275-286. doi: $10.2307 / 40441535$

Hill, L. (2002). On the reasonableness of compelling citizens to 'vote': the Australian case. Polit. Stud. 50, 80-101. doi: 10.1111/1467-9248.00360

Hooghe, L., and Marks, M. (2018). Cleavage theory meets Europe's crises: Lipset, Rokkan, and the transnational cleavage. J. Eur. Public Policy 25, 109-135. doi: 10.1080/13501763.2017.1310279

Hooghe, M., Marien, S., and Pauwels, T. (2013). Where do distrusting voters turn if there is no viable exit or voice option? The impact of political trust on electoral behaviour in the Belgian regional elections of june 2009. Govern. Oppos. 46, 245-273. doi: 10.1111/j.1477-7053.2010. 01338.x

Horton, J. (2012). Political legitimacy, justice and consent. Crit. Rev. Intern. Soc. Political Philos. 15, 129-148. doi: 10.1080/13698230.2012.651015

Huddy, L., Mason, L., and Aarøe, L. (2015). Expressive partisanship: campaign involvement, political emotion, and partisan identity. Am. Political Sci. Rev. 109, 1-17. doi: $10.1017 /$ S0003055414000604

Jones, P., and Hudson, J. (2003). Civic duty and expressive voting: is virtue its own reward? KYKLOS 53, 3-16. doi: 10.1111/1467-6435. 00106

Katz, G., and Levin, I. (2016). A general model of abstention under compulsory voting. Polit. Sci. Res. Methods 6, 489-508. doi: 10.1017/psrm.2016.49 
Kemmers, R. (2017). Channelling discontent? Non-voters, populist party voters, and their meaningful political agency. Eur. J. Cult. Polit. Sociol. 4, 381-406. doi: 10.1080/23254823.2017.1339203

Klosko, G. (2005). Political Obligations. Oxford: Oxford University Press. doi: 10.1093/0199256209.001.0001

Klosko, G. (2018). "Consent theory of political obligation," in The Routledge Handbook of the Ethics of Consent, eds A. Müller and P. Schaber (Oxon/New York: Routledge), 348-358. doi: 10.4324/9781351028264-31

Kriesi, H., Grande, E., Lachat, R., Dolezal, M., Bornschier, S., and Frey, T. (2008). West European Politics in the Age of Globalization. Cambridge, MA: Cambridge University Press. doi: 10.1017/CBO9780511 790720

Kselman, D., and Niou, E. (2011). Protest voting in plurality elections: a theory of voter signaling. Public Choice 148, 395-418. doi: 10.1007/s11127-0109661-2

Landemore, H. (2013). Deliberation, cognitive diversity, and democratic inclusiveness: an epistemic argument for the random selection of representatives. Synthese 190, 1209-1231. doi: 10.1007/s11229-012-0062-6

Lipset, S., and Rokkan,. S. (1967). Party Systems and Voter Alignments: CrossNational Perspectives. New York, NY: The Free Press.

Locke, J. (2013). Two Treatises of Government. ed P. Laslett. Cambridge: Cambridge University Press.

Luhmann, N. (1983). Legitimation durch Verfahren. Frankfurt am Main: Suhrkamp.

Manin, B. (1997). The Principles of Representative Government. Cambridge: Cambridge University Press. doi: 10.1017/CBO9780511659935

Martini, S., and Quaranta, M. (2019). Political support among winners and losers: Within- and between-country effects of structure, process and performance in Europe. Eur. J. Polit. Res. 58, 341-361.

Medeiros, M., and Noël, A. (2014). The forgotten side of partisanship: negative party identification in four Anglo-American democracies. Comp. Polit. Stud. 47, 1022-1046. doi: 10.1177/0010414013488560

Miles, M. R. (2015). Turnout as consent: how fair governance encourages voter participation. Polit. Res. Q 68, 363-376. doi: 10.1177/1065912915573282

Mudde, C. (2007). Populist Radical Right Parties in Europe. Cambridge: Cambridge University Press. doi: 10.1017/CBO9780511492037

Norris, P. (2011). Democratic Deficit. Critical Citizens Revisited. Cambridge: Cambridge University Press.

Owens, D. (2011). The possibility of consent. Ratio 24, 402-421. doi: 10.1111/j.1467-9329.2011.00509.x

Passarelli, G., and Tuorto, D. (2018). The five star movement: purely a matter of protest? The rise of a new party between political discontent and reasoned voting. Party Politics 24, 129-140. doi: 10.1177/1354068816642809

Pateman, C. (1979). The Problem of Political Obligation: A Critical Analysis of Liberal Theory. New York: John Wiley \& Sons. doi: 10.3817/0979041220

Przeworski, A. (2018). Why Bother With Elections? Cambridge: Polity Press.
Ragsdale, L. (2017). "Who are nonvoters?", in The American Nonvoter, eds L. Ragsdale and J. G. Rusk (Oxford: Oxford University Press), ch. 4. doi: 10.1093/acprof:oso/9780190670702.003.0005

Rich, T., and Treece, M. (2018). Losers' and Non-voters' Consent: Democratic satisfaction in the 2009 and 2013 elections in Germany. Govern. Opp. 53, 416-436. doi: 10.1017/gov.2016

Rogers, T., Fox, C. R., and Gerber, A. S. (2013). "Rethinking why people vote: voting as dynamic social expression," in The Behavioral Foundations of Policy, ed E. Shafir (Princeton: Princeton University Press), 91-107. doi: 10.1515/9781400845347-009

Ryabchuk, A. (2016). Voter abstention in South African 2014 elections: beyond the apathy argument. Transformation 92, 37-59. doi: 10.1353/trn.2016.0026

Schnüringer, H. (2018). "What is consent?," in The Routledge Handbook of the Ethics of Consent, eds P. Schaber and A. Müller (Oxon: Routledge), 21-31. doi: 10.4324/9781351028264-3

Schultheis, F. (2017). "Keine Wahl: Wenn langzeitarbeitslose Mitbürger der Demokratie den Rücken kehren," in Gib mir was, was ich wählen kann" - Demokratie ohne Langzeitarbeitslose?: Motive langzeitarbeitsloser Nichtwähler/innen, ed D.F.f.M.a. Rande (Cologne: Herbert von Halem), 9-22.

Simmons, A. J. (1979). Moral Principles and Political Obligations. Princeton Princeton University Press. doi: 10.1515/9780691213248

Singer, P. (1994). Democracy and Disobedience. Suffolk: Gregg Revivals.

Steinberg, J. (1978). Locke, Rousseau, and the Idea of Consent: An Inquiry Into the Liberal-Democratic Theory of Political Obligation. Westport, Conn.: Greenwood Press.

Stockemer, D. (2017). What affects voter turnout? A review article/meta-analysis of aggregate research. Govern. Oppos. 52, 698-722. doi: 10.1017/gov.2016.30

Vandamme, P.-E., and Verret-Hamelin, A. (2017). A randomly selected chamber: promises and challenges. J. Public Deliberation 13:5. doi: 10.16997/jdd.271

Von Soest, C., and Grauvogel, J. (2017). Identity, procedures and performance: how authoritarian regimes legitimize their rule. Contemp. Politics 23, 287-305. doi: 10.1080/13569775.2017.1304319

Wertheimer, A. (2000). What is consent? and is it important? Buff. Crim. Law Rev. 3, 557-583. doi: 10.1525/nclr.2000.3.2.557

Winkler, A. (1993). Expressive voting. N. Y. U. Law Rev. 68, 330-388.

Conflict of Interest: The author declares that the research was conducted in the absence of any commercial or financial relationships that could be construed as a potential conflict of interest.

Copyright (C) 2020 Ramelet. This is an open-access article distributed under the terms of the Creative Commons Attribution License (CC BY). The use, distribution or reproduction in other forums is permitted, provided the original author $(s)$ and the copyright owner(s) are credited and that the original publication in this journal is cited, in accordance with accepted academic practice. No use, distribution or reproduction is permitted which does not comply with these terms. 